J. Clin. Chem. Clin. Biochem.

Vol. 24, 1986, pp. 831-839

(C) 1986 Walter de Gruyter \& Co. Berlin - New York

\title{
Measurements of Prednisolone and Some of its Metabolites, in Urine of Patients after Orthotopic Liver Transplantation, as a Means of Monitoring Prednisolone Absorption
}

\author{
By B. J. Koopman, J. C. van der Molen
}

Central Laboratory for Clinical Chemistry

E. B. Haagsma, J. R. Huizenga

Department of Medicine, Division of Hepatology

R. A.F. Krom ${ }^{1}$ )

Department of Surgery

G. T. Nagel

Central Laboratory for Clinical Chemistry

C. H. Gips

Department of Medicine, Division of Hepatology and

B. G. Wolthers

Central Laboratory for Clinical Chemistry

University Hospital, Groningen, The Netherlands

(Received March 25/June 25, 1986)

Summary: In patients who had undergone orthotopic liver transplantation, malabsorption of prednisolone or increased metabolism of prednisolone was suspected. In order to rule out this possibility, urinary prednisolone, and some of its metabolites, viz prednisone and $6 \beta$-hydroxyprednisolone, were determined by means of a gas chromatographic assay. To evaluate this assay aliquots of a pooled urine from several of our patients were analysed in multiplicate $(\mathrm{n}=10)$. Mean prednisone, prednisolone and $6 \beta$-hydroxyprednisolone concentrations of $1.9 \mathrm{mg} / 1,6.3 \mathrm{mg} / \mathrm{l}$ and $4.1 \mathrm{mg} / \mathrm{l}$, respectively, were found with the following respective dayto-day coefficients of variation: $12.3 \%, 5.2 \%$ and $5.3 \%$. Amounts of prednisolone metabolites excreted in the urine of these patients were correlated with the ingested daily dose of prednisolone. It was concluded that overall absorption of prednisolone in these patients was adequate and not influenced by shortage of bile acids in the gastro-intestinal tract, or by steatorrhoea, both caused by external bile drainage. In addition there was no evidence for increased metabolism of prednisolone.

1) Present Address: Liver Transplantation Surgery, Mayo Clinic, Rochester, MN, USA. 
Die Bestimmming von Prednisolon und einigen seiner Metabolite im Harn zur Verlaufsbeobachtung der Prednisolon-Resorption bei Patienten nach orthotoper Lebertransplantation

Zusammenfassung: Bei Patienten mit orthotoper Lebertransplantation wurde Malabsorption bzw. erhöhter Umsatz von Prednisolon vermutet. Zur Klärung wurden Prednisolon und einige seiner Metabolite (Prednison, $6 \beta$-Hydroxyprednisolon) in Harn gaschromatographisch bestimmt. Zur Charakterisierung des Verfahrens wurden 10-fach-Bestimmungen an einem gemischten Pool-Harn durchgeführt. Die Präzision von Tag zu Tag betrug für Prednison (1,9 mg/l) 12,3\%, für Prednisolon $(6,3 \mathrm{mg} / \mathrm{l}) 5,2 \%$ und für $6 \beta$-Hyddroxyprednisolon $(4,1 \mathrm{mg} / \mathrm{l})$ 5,3\%. Die Ausscheidung der Prednisolon-Metabolite wurde mit der aufgenommenen Dosis korreliert. Wir schließen, daß die Gesamt-Resorption von Prednisolon bei diesen Patienten angemessen und unbeeinflußt (Verminderung der Gallensäuren im Gastrointestinaltrakt, Steatorrhoe infolge externer Gallendrainage) war. Es besteht kein Anhalt für einen gesteigerten Prednisolonumsatz.

\section{Introduction}

For the immunosuppressive regime after organ transplantation there are in principle two choices: ciclosporin/predniso(lo)ne and azathioprine/predniso(lo)ne. The liver transplantation group at Groningen has so far used the combination azathioprine/prednisolone in 48 orthotopic liver transplantations in 45 patients. Azathioprine does not influence the bioavailability of prednisolone and thus these two drugs can be used in combination (1).

Prednisolone is well absorbed from the gastro-intestinal tract (2). Even after extensive small bowel resection, resulting in a jejunum length of $100 \mathrm{~cm}$ and a jejunostomy, prednisolone was well resorbed (3).

Corticosteroids, such as prednisolone, are eventually excreted in the urine, together with their metabolites (4). After a dose of $10 \mathrm{mg}$ of prednisolone given to 6 healthy volunteers, between $11 \%$ and $19 \%$ of the dose was excreted unmetabolised in the urine within 24 hours (5). After a dose of about $50 \mathrm{mg}$ given to 5 healthy volunteers, between $21 \%$ and $33 \%$ was recovered in the urine within 24 hours (6). The higher percentage of excreted prednisolone can be ascribed to a lower percentage of protein binding in serum, when the concentration of the drug is increased. Metabolites of prednisolone e.g. prednisone $(6,7)$, $6 \beta$-hydroxyprednisolone (6), $20 \beta$-hydroxyprednisolone (7) and $20 \beta$-hydroxyprednisone (7) are also excreted in the urine. Neither biliary nor faecal excretion is of any quantitative importance (4).

In some of our patients, who underwent liver transplantation, malabsorption of prednisolone was seriously considered on clinical grounds during episodes in the postoperative treatment. During the first weeks after liver transplantation there is severe steatorrhoea. This phenomenon is in part due to loss of bile (including bile acids) via an external bile drainage. Regarding prednisolone absorption and metabolism, it was of interest to enquire: a) whether absorption is influenced by steatorrhoea

b) whether absorption is influenced by a shortage of bile acids, and

c) whether liver transplantation affects the metabolism of prednisolone.

Our laboratory was asked to investigate prednisolone absorption and metabolism in these patients. Prednisolone resorption can be monitored by determining its concentration in serum. However, this requires protocolised serum sampling at regular intervals during the day. Therefore measurements of urinary excreted prednisolone and prednisolone metabolites in 24 hour portions, which is easier to perform and less troublesome to the patient, seems to be more appropriate. In order to establish intra-individual variances and variances due to malabsorption or to decreased or increased metabolism of prednisolone, we monitored urinary prednisolone and its metabolites in 10 orthotopic liver transplant patients, using a gas chromatographic procedure similar to that for the determination of bile alcohols in urine (9). The excreted amount of the bile alcohol 27 -nor- $5 \beta$-cholestane-3 $\alpha, 7 \alpha, 12 \alpha, 24,25$-pentol was also measured within the same gas chromatographic run. This bile alcohol is endogenously synthesised in the liver and thought to be a side product arising during biosynthesis of cholic acid from cholesterol (10); the excreted amount can therefore be used as a parameter of liver function $(11-13)$, and in our particular case as an index of the postoperative recovery process. In addition it can also be used as a urine sampling parameter; like creatinine, which is more commonly measured as a urine sampling parameter, 27 -nor-5 $\beta$ cholestane-3 $\alpha, 7 \alpha, 12 \alpha, 24,25$-pentol is apparently not subject to strong fluctuations. The results obtained in this study show that prednisolone absorption, even during periods of steatorrhoea in orthotopic liver transplanted patients, is not markedly disturbed. Furthermore, there was no evidence for enhanced or decreased metabolism of this drug. 


\section{Materials and Methods}

\section{Materials}

Sep-Pak C-18 cartridges were from Waters Ass. Inc. (Milford Ma, USA), prednisolone and prednisone were from Sigma Chemical Company (St. Louis, Mo, USA), $6 \beta$-hydroxyprednisolone and methyldeoxycholate (used as internal standard in the gas chromatographic assay) were from Steraloids Inc. (Wilton, NH, USA), and Helix pomatia intestinal juice from Pharmindustrie (Clichy, France). A solution of $2 \%$ methoxamine$\mathrm{HCl}$ in pyridine ('MOX') was from Pierce Chemical Co (Illinois, USA). Trimethylbromosilane was purchased from Fluka AG (Buchs, Switzerland). All other chemicals were of analytical grade and purchased from Merck (Darmstadt, FRG). The fused silica capillary column CP-Sil-5-CB, i.d. $0.20-0.22 \mathrm{~mm}$, was from Chrompack (Middelburg, The Netherlands).

\section{Methods}

Determinations of urinary prednisolone, prednisone and $6 \beta$-hydroxyprednisolone

Prednisolone, prednisone, $6 \beta$-hydroxyprednisolone and 27 nor-5 $\beta$-cholestane-3 $\alpha, 7 \alpha, 12 \alpha, 24,25$-pentol were determined by gas chromatography as previously described for the determination of bile alcohols (9). The method was only slightly modified.

Depending on the expected concentration of prednisolone metabolites, 0.2 to $1 \mathrm{ml}$ of centrifuged urine was diluted with distilled water to a volume of $2 \mathrm{ml}$. Sodium acetate buffer $(\mathrm{pH}$ $4.7,5 \mathrm{~mol} / \mathrm{l})(100 \mu \mathrm{l})$ and Helix pomatia juice $(30 \mu \mathrm{l})$ were added. The mixture was incubated for $20 \mathrm{~h}$ at $37^{\circ} \mathrm{C}$. Then as internal standard $50 \mu \mathrm{l}$ of an ethanolic solution, containing 24.4 $\mathrm{mg} / \mathrm{l}$ methyldeoxycholate, was added and the mixture applied to a Sep-Pak C18 cartridge, which was previously washed with $10 \mathrm{ml}$ of methanol and $10 \mathrm{ml}$ of distilled water, respectively. After washing three times with $5 \mathrm{ml}$ of distilled water the cartridge was eluted with two portions of $2 \mathrm{ml}$ of methanol. The eluate was evaporated to dryness at $60^{\circ} \mathrm{C}$ unter $\mathrm{N}_{2}$. Derivatisation to methoxime-trimethylsilyl derivatives was then performed as follows. Methoxamine solution $(100 \mu \mathrm{l})$ was added and the solution heated for $3 \mathrm{~h}$ at $60^{\circ} \mathrm{C}$. The solvent was evaporated at $60^{\circ} \mathrm{C}$ under $\mathrm{N}_{2}$. A freshly prepared mixture of bistrimethylsilylacetamide/trimethylbromo silane/pyridine $(4+1+5, v / v)(100 \mu l)$ was added and the mixture allowed to stand for $20 \mathrm{~h}$ at $4{ }^{\circ} \mathrm{C}$. After the addition of $5 \mathrm{ml}$ of hexane and $5 \mathrm{ml}$ of $0.1 \mathrm{~mol} / 1 \mathrm{HCl}$ solution, the product was purified as follows. The mixture was vortexed, then centrifuged, and the aqueous layer was removed. Sodium hydroxide $(1 \mathrm{~mol} / \mathrm{l})$ $(2 \mathrm{ml})$, was added, followed by vortexing and centrifuging. The aqueous layer was then removed and $3 \mathrm{ml}$ of distilled water was added. Following vortexing and centrifuging, the aqueous layer was removed; the hexane layer was again washed with $3 \mathrm{ml}$ of distilled water. After vortexing and centrifuging and removal of the water layer, the hexane solution was evaporated to dryness at $60^{\circ} \mathrm{C}$ under nitrogen. After addition of $100 \mu \mathrm{l}$ of hexane $2 \mu \mathrm{l}$ was introduced by splitless injection into a HewlettPackard $5880 \mathrm{~A}$ gas chromatograph equipped with a split/ splitless injection device for capillary columns and flame ionisation detection. Helium was used as carrier gas with a flow rate of $1.5 \mathrm{ml} / \mathrm{min}$. A $25-\mathrm{m}$ fused silica CP-Sil-5-CB capillary column was employed. Injector and detector temperature were $260^{\circ} \mathrm{C}$ and $290^{\circ} \mathrm{C}$ respectively. Following injection the oven temperature was kept at $100^{\circ} \mathrm{C}$ for 2 minutes, then programmed at a rate of $25^{\circ} \mathrm{C} /$ minute to a temperature of $215^{\circ} \mathrm{C}$ and subsequently, at a rate of $1.75^{\circ} \mathrm{C} /$ minute to a final temperature of $295^{\circ} \mathrm{C}$. Quantification was done by comparison of peak areas relative to that of the internal standard (methyldeoxycholic acid).

\section{Determination of fat in feces}

Determinations of fat in feces were performed as described elsewhere (14).

\section{Patients (tab. 1)}

We studied 10 patients, 3 males and 7 females, median age 39 years (range 4-49). They were transplanted because of primary biliary cirrhosis (5), chronic idiopathic cirrhosis (3), erythropoietic protoporphyria (1) and biliary atresia (1). Immune suppression consisted of prednisolone and azathioprine. On the day of operation and the first two days after the operation, 7 of the 10 patients received additional methylprednisolone (1000$2500 \mathrm{mg}$ ). Methylprednisolone is also excreted in the urine, partly as such and also in the form of other metabolites; although assay methods are available, we did not measure its concentration. The observation period for this study was median 35 days (range $28-86$ ) from the day of the orthotopic liver transplantation.

Faecal fat excretion (g per day) was measured once a week. Almost all patients had severe steatorrhoea during the whole observation period; only three patients had periods with only moderately increased faecal fat $(5-10 \mathrm{~g}$ per day). Bile loss via external bile drainage lasted $22-70$ days.

\section{Samples}

Urine samples were stored at $-20^{\circ} \mathrm{C}$ until analysis. A pooled urine was made by mixing urine samples obtained from several patients.

Tab. 1. Presentation of the 10 patients who underwent orthotopic liver transplantation and in which prednisolone kinetics were monitored.

\begin{tabular}{|c|c|c|c|c|c|c|c|}
\hline \multirow[t]{2}{*}{ Patient } & \multirow{2}{*}{$\begin{array}{l}\text { Age at } \\
\text { orthotopic } \\
\text { liver trans- } \\
\text { plantation } \\
\text { (years) }\end{array}$} & \multirow[t]{2}{*}{ Sex } & \multirow[t]{2}{*}{ Diagnosis } & \multirow{2}{*}{$\begin{array}{l}\text { Observation } \\
\text { period } \\
\text { (days after } \\
\text { orthotopic liver } \\
\text { transplantation) }\end{array}$} & \multirow{2}{*}{$\begin{array}{l}\text { Duration } \\
\text { of open } \\
\text { bile-drain } \\
\text { (days) }\end{array}$} & \multicolumn{2}{|c|}{$\begin{array}{l}\text { Faecal fat during } \\
\text { observation time } \\
\text { (g/d) }\end{array}$} \\
\hline & & & & & & Median & Range \\
\hline $\mathbf{A}$ & 35 & $\sigma^{\pi}$ & chronic idiopathic cirrhosis & $0-40$ & 35 & 34 & $(18-72)$ \\
\hline B & 49 & ơ & primary biliary cirrhosis & $0-41$ & 36 & 40 & $(4-43)$ \\
\hline$\overline{\mathbf{C}}$ & 46 & q & primary biliary cirrhosis & $0-29$ & 27 & 18 & $(14-80)$ \\
\hline D & 22 & ơ & chronic idiopathic cirrhosis & $9-43$ & 25 & 38 & $(19-53)$ \\
\hline E & 43 & q & primary biliary cirrhosis & $0-48$ & 28 & 8 & $(5-17)$ \\
\hline $\mathrm{F}$ & 48 & oq & primary biliary cirrhosis & $0-28$ & 22 & 41 & $(31-51)$ \\
\hline G & 18 & o & chronic idiopathic cirrhosis & $0-35$ & 35 & 11 & \\
\hline $\mathrm{H}$ & 4 & q & biliary atresia & $0-34$ & 24 & 3 & $(2-9)$ \\
\hline$\hat{\mathrm{I}}$ & 45 & $\stackrel{+}{+}$ & primary biliary cirrhosis & $0-85$ & 29 & 37 & $(14-76)$ \\
\hline $\mathbf{K}$ & 29 & $\hat{\sigma}$ & erythropoietic protoporphyria & $0-71$ & 70 & 33 & $(11-141)$ \\
\hline
\end{tabular}


$\stackrel{\pi}{\check{0}}$
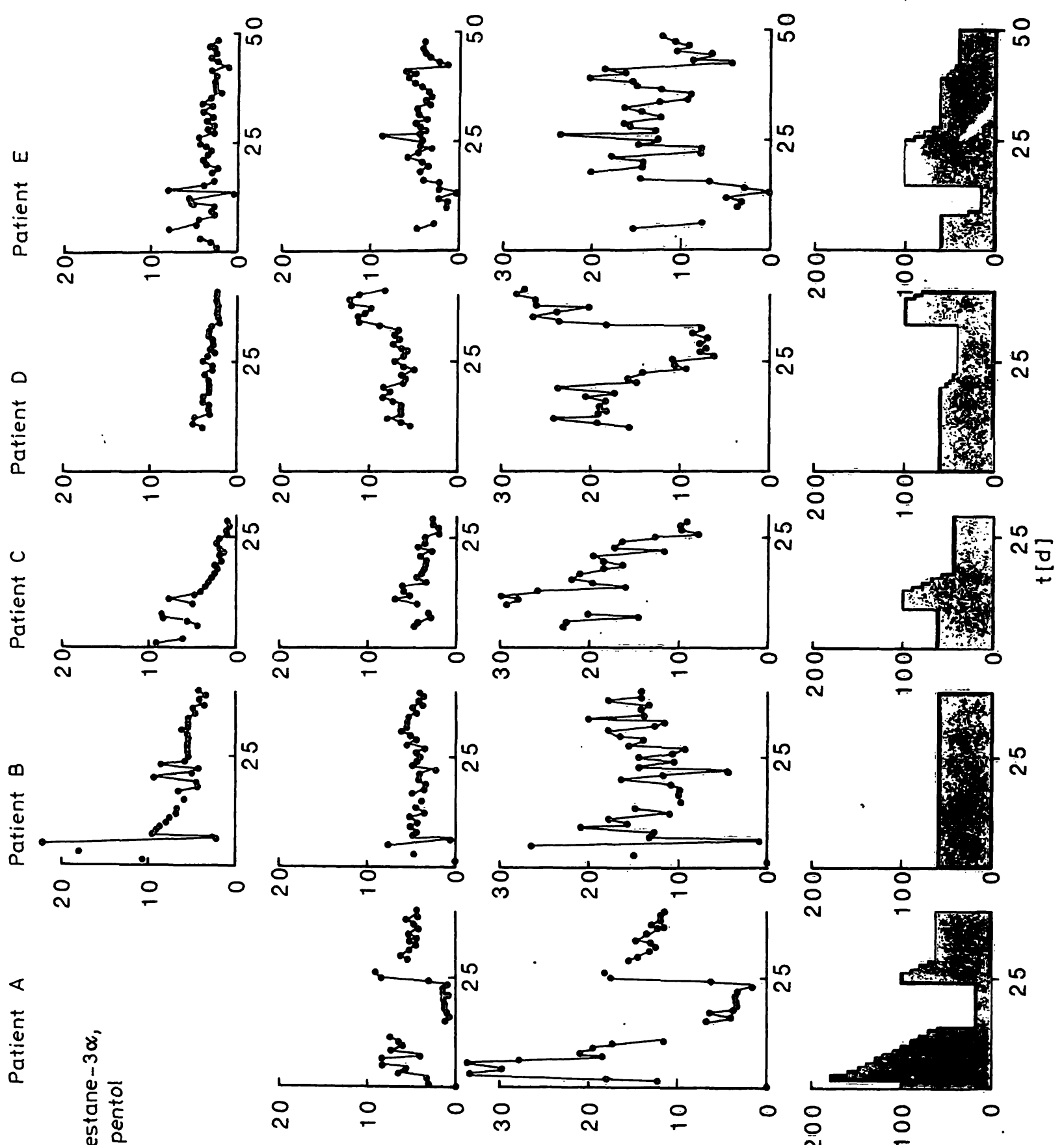

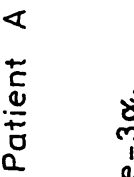

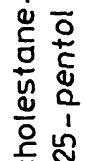

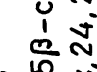

$>\ln y^{\circ}$

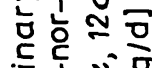

ปั่

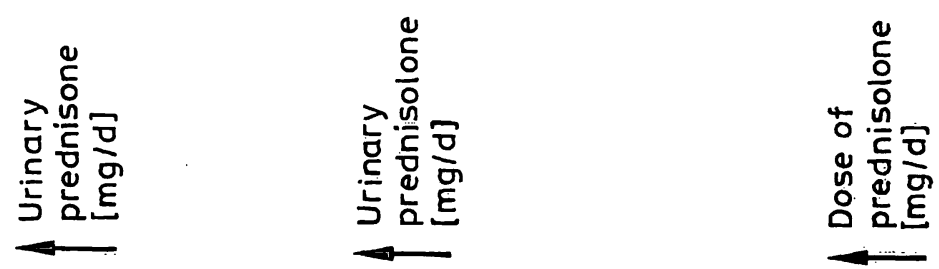


$\stackrel{0}{\circ}$
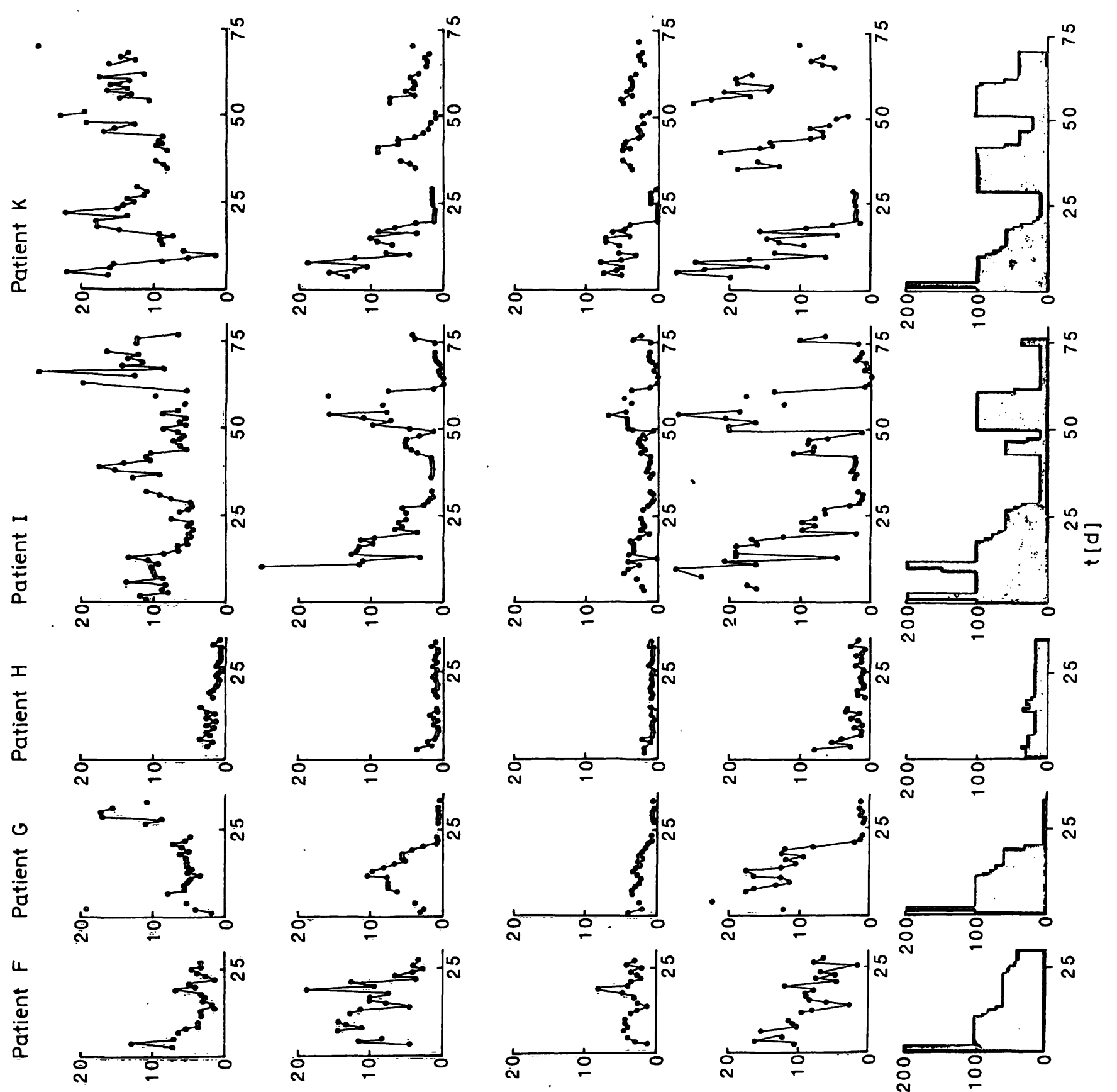

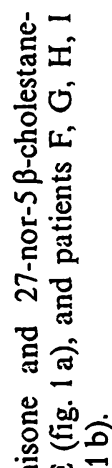

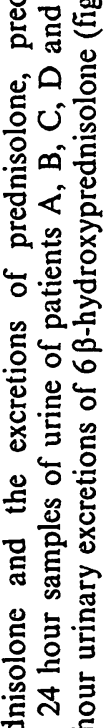
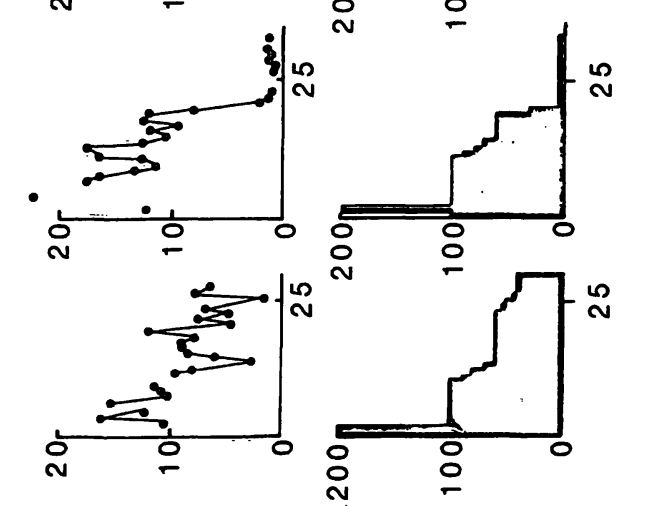

总号至

岹.

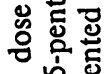

त స్․․

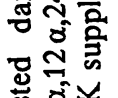

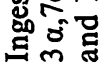

$\dot{\Delta}$

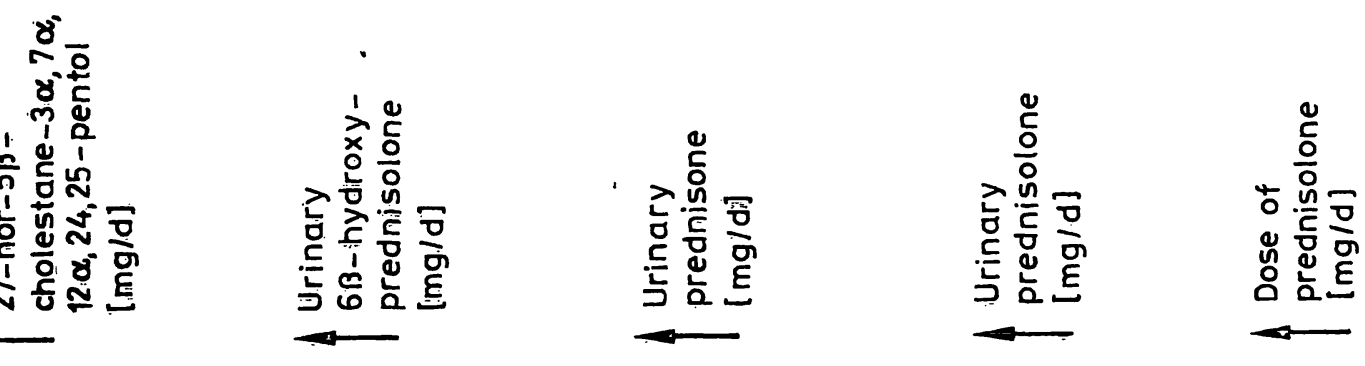




\section{Results}

Gas chromatographic peaks of methoxime-trimethylsilyl-derivatives of prednisolone and metabolites, derived from the urine samples of our patients, were identified by their retention times and mass spectra (in comparison with the reference compounds). One problem in the gas chromatographic analysis of the methoxime derivatives of steroids is that an oxo group gives rise to two geometric isomers of the syn/ anti type (15). Therefore two peaks can arise from a single substance (e.g. from prednisone or $6 \beta$-hydroxyprednisolone). In the case of prednisolone, however, these two peaks have nearly the same retention time. Therefore in the quantitative analysis of prednisolone and its metabolites, peak areas including the two isomers were determined relative to the peak area of the internal standard, and compared with standards.

Calibration curves for prednisone, prednisolone and $6 \beta$-hydroxyprednisolone, employing the area ratios of the prednisone/internal standard, prednisolone/ internal standard and $6 \beta$-hydroxyprednisolone/internal standard were all found to be linear in the range $0-20 \mu \mathrm{g}$. The detection limit for all three substances is about $1 \mathrm{ng}$. To evaluate the gas chromatographic assay we measured prednisone, prednisolone and $6 \beta$ hydroxyprednisolone in multiplicate in a pooled urine. The day-to-day coefficients of variation $(n=10)$ and the corresponding mean values for prednisone, prednisolone and $6 \beta$-hydroxyprednisolone were 1.9 $\mathrm{mg} / \mathrm{l}$, C.V. $12.3 \%, 6.3 \mathrm{mg} / \mathrm{l}$, C.V. $5.2 \%$, and $4.1 \mathrm{mg} / \mathrm{l}$, C.V. $5.3 \%$, respectively. In addition, prednisone, prednisolone and $6 \beta$-hydroxyprednisolone were added in varying amounts to aliquots of urine, in order to determine recovery. For all three steroids this was in the range of $90-110 \%$.

After having established that determinations of urinary prednisone, prednisolone and $6 \beta$-hydroxyprednisolone were reproducible and that the recovery of added prednisone, prednisolone and $6 \beta$-hydroxyprednisolone was correct, urinary daily excretions of prednisone, prednisolone, $6 \beta$-hydroxyprednisolone and 27-nor-5 $\beta$-cholestane- $3 \alpha, 7 \alpha, 12 \alpha, 24,25$-pentol were determined and correlated with the ingested daily dose. Figure 1 shows the ingested daily dose of prednisolone and the excretions of prednisolone, prednisone and 27-nor-5 $\beta$-cholestane- $3 \alpha, 7 \alpha$, $12 \alpha, 24,25$-pentol in 24 hour urine portions of patients A, B, C, D and E (fig. $1 \mathrm{a}$ ). In figure $1 \mathrm{~b}$ the same data are supplemented with 24 hour excretions of $6 \beta$-hydroxyprednisolone in the remaining patients $F$, $\mathrm{G}, \mathrm{H}, \mathrm{J}$ and $\mathrm{K}$.
The daily excreted amounts of prednisolone and its metabolites sometimes fluctuate strongly and unexpectedly. This phenomenon was usually observed in the presence of concomitant fluctuations in the excreted amounts of the bile alcohol 27 -nor-5- $\beta$-cholestane-3 $\alpha, 7 \alpha, 12 \alpha, 24,25$-pentol, suggesting incorrect urine sampling as mentioned in the introduction. In order to evaluate possible incorrect urine sampling we compared the urinary daily excretions of 27 -nor$5 \beta$-cholestane- $3 \alpha, 7 \alpha, 12 \alpha, 24,25$-pentol and urinary daily excretions of creatinine of patients $B$ and $F$ (fig. 2 ). Indeed strong fluctuations in creatinine values accompany those of 27 -nor- $5 \beta$-cholestane- $3 \alpha, 7 \alpha$, $12 \alpha, 24,25$-pentol confirming our supposition. Daily urinary excretions of prednisolone by patients $B$ and $\mathrm{F}$ are also expressed as $\mathrm{g} / \mathrm{mol}$ creatinine and $\mathrm{g} / \mathrm{g} 27$ nor-5 $\beta$-cholestane-3 $\alpha, 7 \alpha, 12 \alpha, 24,25$-pentol (fig. 2).

Representative steroid profiles of a patient who underwent an orthotopic liver transplantation (3 A) and another patient, not suffering from a liver disease (B) are shown in figure 3. Both patients received an oral dose of $60 \mathrm{mg}$ of prednisolone per day. Figure 3 shows peaks of methyldeoxycholate (internal standard, peak 1), prednisone (peaks $2 \mathrm{~A}$ and $2 \mathrm{~B}$ ), prednisolone (peak 3), $20 \beta$-hydroxyprednisolone (peaks 4, $5,7), 6 \beta$-hydroxyprednisolone (peaks 6,8 ) and the bile alcohol 27 -nor-5 $\beta$-cholestane-3 $\alpha, 7 \alpha, 12 \alpha, 24,25$ pentol (peak 12). The mass spectrum of peak 9 , which is very similar to mass spectra retrieved from peaks 10 and 11 , is presented in figure 4 and is presumably that of a prednisolone metabolite.

\section{Discussion}

In some patients, who had undergone orthotopic liver transplantation, immunosuppression was thought to be insufficient during certain episodes in the postoperative treatment. Therefore the clinicians asked our laboratory to ascertain whether prednisolone was adequately adsorbed. One way of showing this is to measure the urinary excretion of unchanged prednisolone and prednisolone metabolites in comparison with normals. These measurements do not permit the determination of the exact percentage of absorption, but are sufficiently precise to establish whether or not the greater part of this drug has been absorbed. In addition they can show whether the metabolism of the drug in our patients is different from normals.

Our study, performed on 10 orthotopic liver transplant patients, shows that prednisolone absorption and metabolism can be adequately monitored by measuring the excretion of this drug and its metab- 

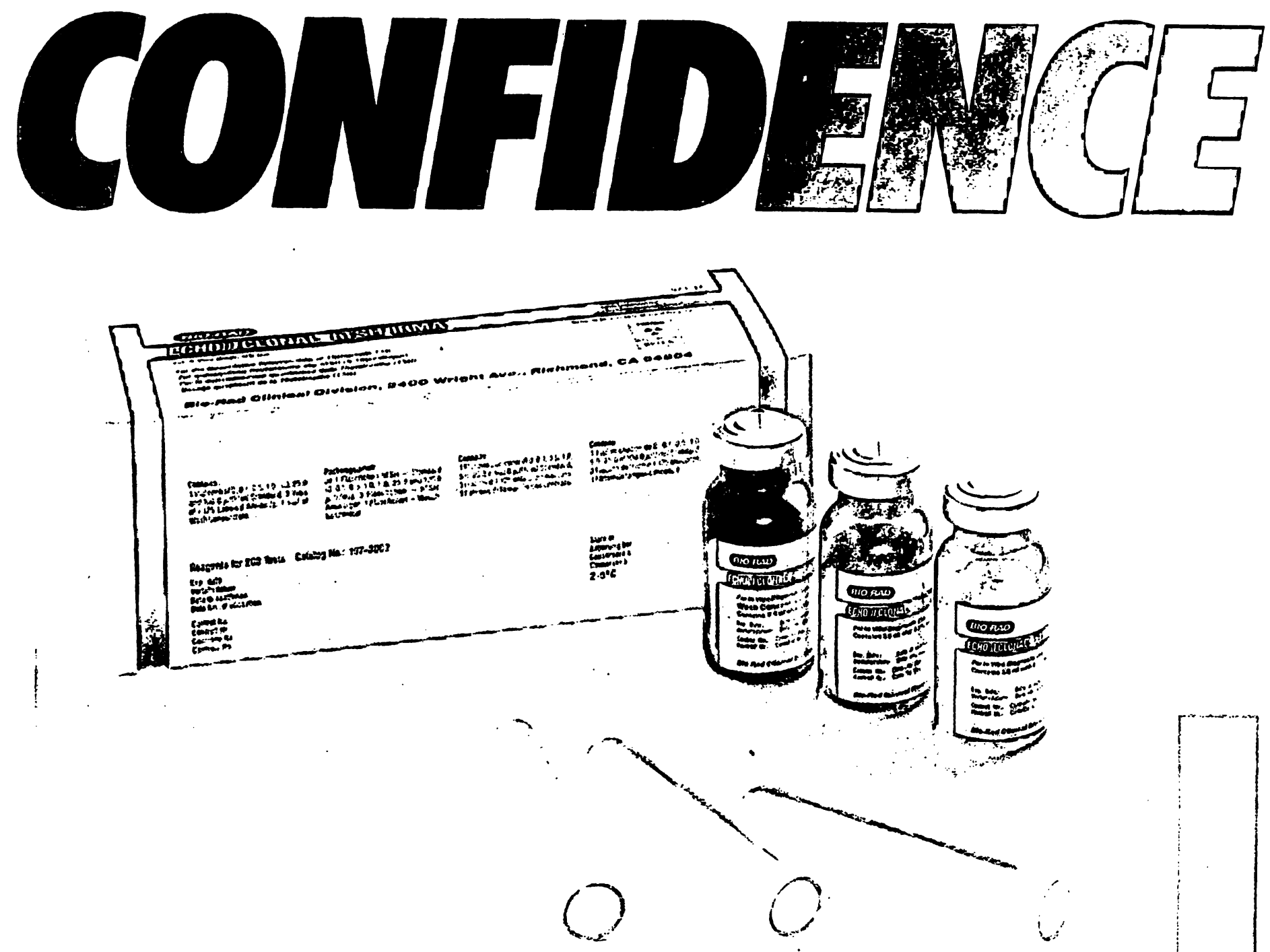

By combining advanced IRMA technology with monoclonal antibody specificity,

Bio-Rad's new EchoClonal TSH assay provides an ultrasensitive test for human TSH in serum.

Just two pipetting stages followed by 22 hour incubation at room temperature are required, and $0.1 \mu \mathrm{lU} / \mathrm{ml}$ standard enhances the accuracy of the determinations.

Bio-Rad's panel of thyroid function tests also includes the Quantimune

Free T-4 assay that provides a quantitative measure of free thyroxine over the range 0 to $10 \mathrm{ng} / \mathrm{d}$.

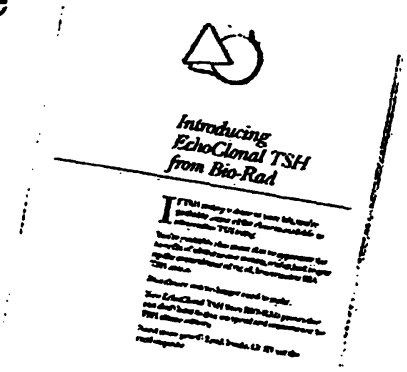

Contact Bio-Rad today for more information.

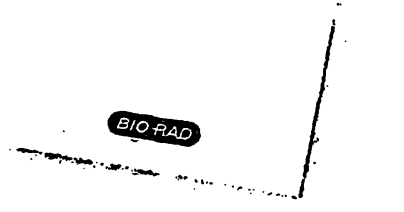

\section{With a sensitivity of} $0.02 \mu \mathrm{IU} / \mathrm{ml}$ over the range of $0-100 \mu \mathrm{IU} / \mathrm{ml}$, hyperthyroid, hypothyroid and euthyroid states can be confidently differentiated with just one simple-to-use, coated-tube assay.

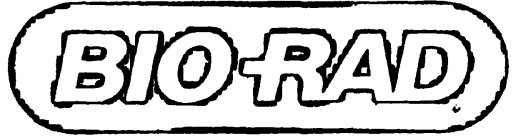

Australia: Hornsby. Tel: 008-224354.

Austria: Vienna. Tel: (0222) 828901.

Canada: Mississauga. Tel: (416) 6240713.

France: Paris. Tel: (01) 5455010.

German Federal Republic: Munich. Tel: (089) 1499050. Hong-Kong: Tel: 5-470333/470616.

Italy: Milan. Tel: (02) 2138751.

Japan: Tokyo. Tel: (03) 4315181.

The Netherlands: Utrecht. Tel: (030) 881141.

Switzerland: Glattbrugg. Tel: (01) 8101677.

United Kingdom: Watford. Tel: (0923) 40322.

USA: Richmond, California. Tel: (415) 2344130. 


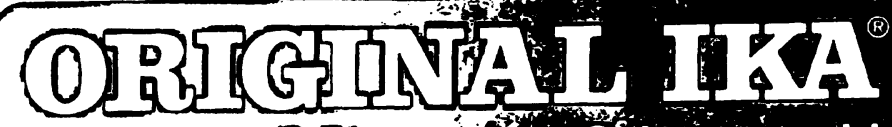

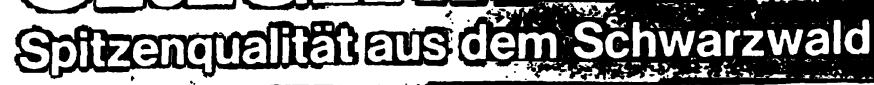

Beispiel:

DKA-Schlauchpumpen

- Geeignet je nach Ausführung zum:

Saugen, Fördern, Umwälzen und Dosieren von

Flüssigkeiten und Gasen.

- Drehzahlgeregelte

Antriebseinheit

(1) Auswechsel-

bare

Pumpköpfe

und zwei

bis sechs

Pumprollen

- Fernsteuerung

folgender

Funktionen

möglich: Lauf,

Überlastsignal,

max. Drehzahl, Fremdspannungssteuerung usw.

- IKA ${ }^{\circledast}$ denkt für seine Kunden.

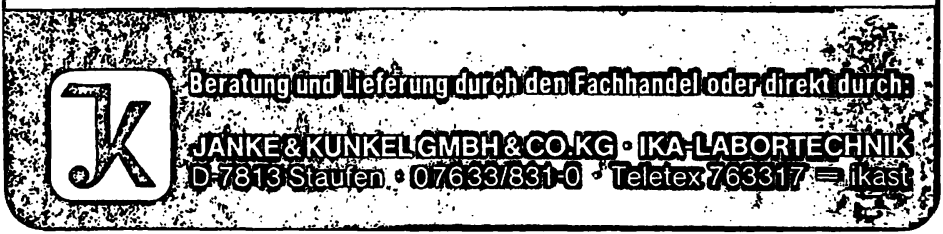

D. M. Goldberg · M. Werner (Editors)

\section{Selected Topics in Clinical Enzymology}

Proceedings (selected) of the Third International Congress of Clinical Enzymology Salzburg, Austria, September 6-9, 1981

$1983.17 \mathrm{~cm} \times 24 \mathrm{~cm}$. XVIII, 362 pages. With numerous illustrations. Hardcover. DM 160,-; approx. US-\$72.75

ISBN 3110096889

This book contains 27 contributions providing comprehensive cover of the application of enzymes in four important aspects of Clinical Enzymology:

Enzymes in Cancer - Enzymes in Blood Pressure Regulation - Enzymes in Blood Coagulation - Enzymes in Diseases of Heart and Muscle.

By means of carefully selected reviews and original articles, the reader is brought up to date with the latest advances in these topics. An Author Index and a Comprehensive Subject Index are included.

Prices are subject to change without notice

de Gruyter · Berlin · New York

\section{Trace Element}

Analytical Chemistry in Medicine and Biology

Volume 3

\section{Proceedings of the Third International}

Workshop - Neuherberg,

Federal Republic of Germany, April 1984

\section{Editors P. Brätter, P. Schramel}

1984. $17 \mathrm{~cm} \times 24 \mathrm{~cm}$. XVI, 763 pages. Numerous illustrations.

Hardcover. DM 240,-; approx. US \$80.00 ISBN 3110098210

The proceedings contained in this volume are specifically concerned with new developments in the field of the essential trace elements selenium, zinc and manganese as well as with current problems in analysis, nutrition and medicine. The actual state of knowledge about other recently recognized essential trace elements also played a dominant role. 

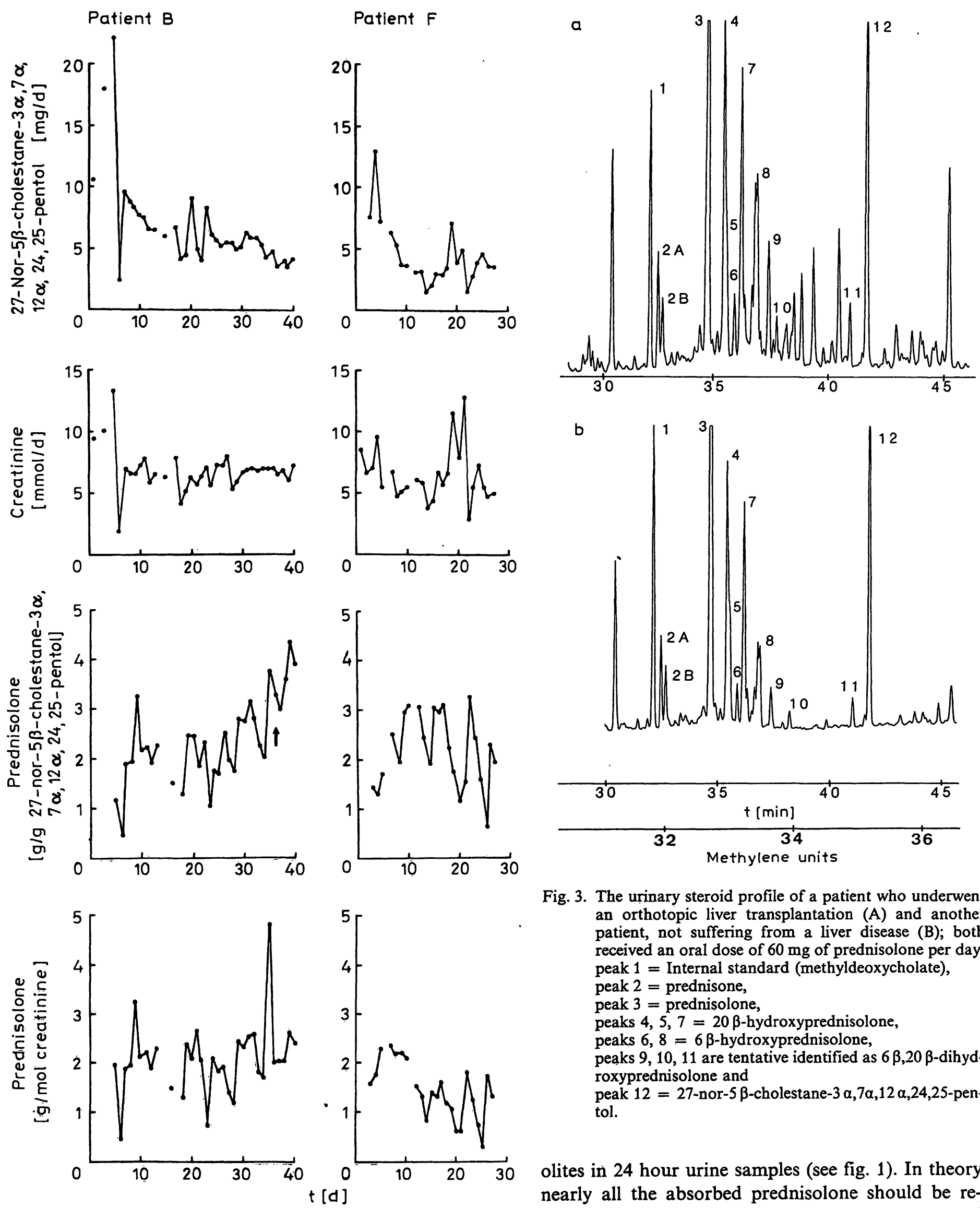

Fig. 2. Daily urinary excretion of 27 -nor-5 $\beta$-cholestane$3 \alpha, 7 \alpha, 12 \alpha, 24,25$-pentol and creatinine, and urinary excretion of prednisolone expressed as $\mathrm{mg} / \mathrm{mg} 27-$ nor- $5 \beta$ cholestane-3 $\alpha, 7 \alpha, 12 \alpha, 24,25$-pentol and $\mathrm{mg} / \mathrm{mmol}$ creatinine of patients $B$ and $F$.
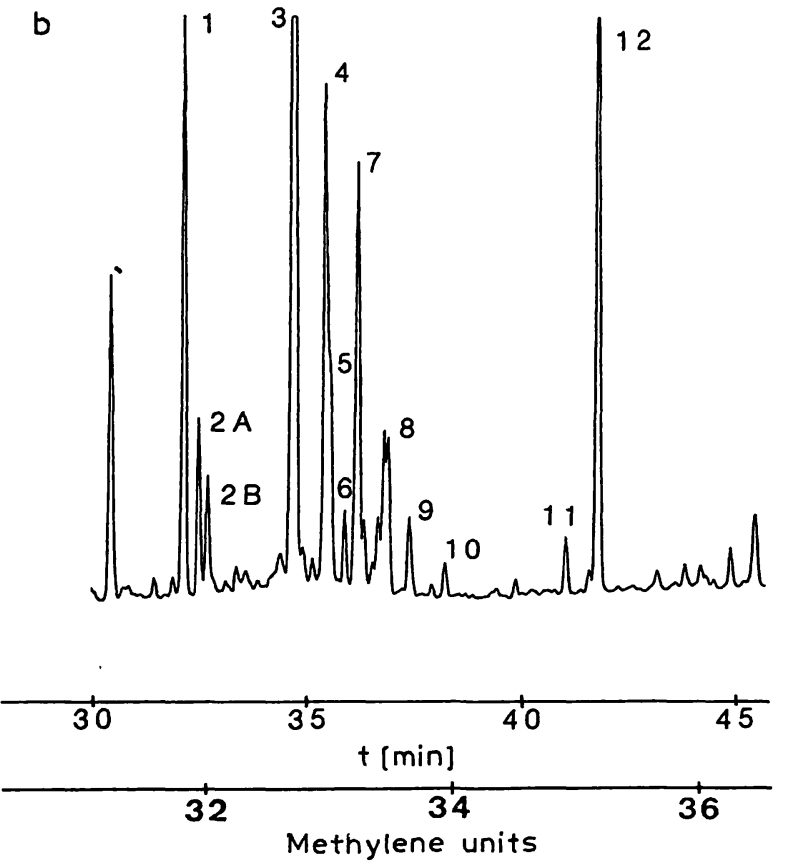

Fig. 3. The urinary steroid profile of a patient who underwent an orthotopic liver transplantation (A) and another patient, not suffering from a liver disease (B); both received an oral dose of $60 \mathrm{mg}$ of prednisolone per day; peak 1 = Internal standard (methyldeoxycholate),

peak 2 = prednisone,

peak 3 = prednisolone,

peaks $4,5,7=20 \beta$-hydroxyprednisolone, peaks $6,8=6 \beta$-hydroxyprednisolone,

peaks $9,10,11$ are tentative identified as $6 \beta, 20 \beta$-dihydroxyprednisolone and

peak $12=27$-nor-5 $\beta$-cholestane-3 $\alpha, 7 \alpha, 12 \alpha, 24,25$-pentol.

olites in 24 hour urine samples (see fig. 1). In theory nearly all the absorbed prednisolone should be recovered in the urine, when the unaltered compound together with all its metabolites are quantitatively measured, because biliary and faecal excretion are normally virtually absent (4). However a more practical approach is to measure only the urinary excretion 


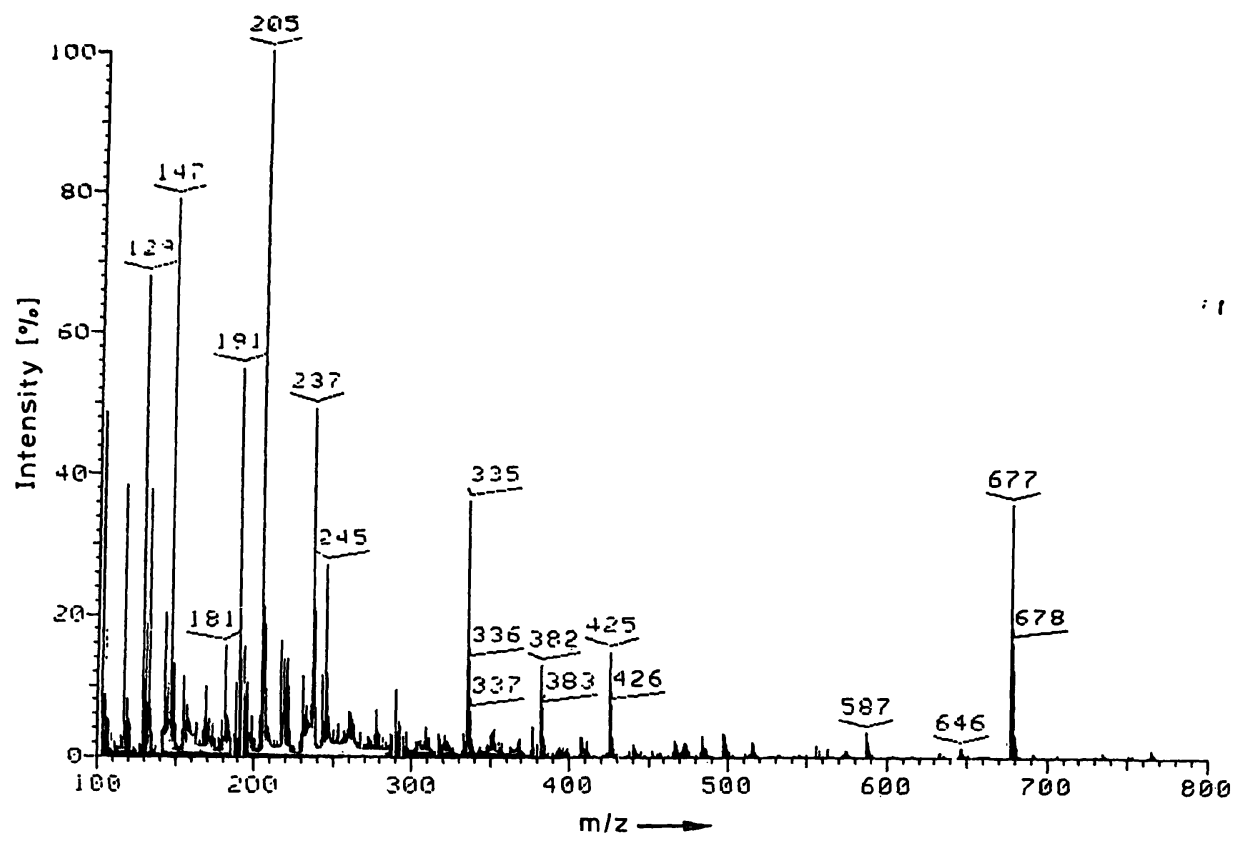

Fig. 4. Mass spectrum of the tentatively identified prednisolone metabolite: $6 \beta, 20 \beta$-dihydroxyprednisolone.

of prednisolone itself, since roughly about $25 \%$, of an ingested dose of $40 \mathrm{mg}$ prednisolone or more per day, is excreted unmetabolised. Such a percentage was also found by others in 5 normal persons after a dose of $50 \mathrm{mg}$ (6). At lower doses of prednisolone that percentage recovery of unchanged prednisolone in the urine decreases, which is also in accordance with other reports (5). Another conclusion to be drawn from our measurements is that prednisolone absorption in liver transplantated persons appears to be practically complete in most cases, as the excreted amount closely follows the ingested dose and approaches the above-mentioned $25 \%$. Moreover the metabolic profile is nearly identical with that of normal persons (see fig. 3), suggesting, that the metabolism of prednisolone is not fundamentally different. As a consequence, the excretions of prednisolone metabolites, such as prednisone and $6 \beta$-hydroxyprednisolone, also correlates well with the ingested dose of prednisolone. Even when a bile drain is present, absorption continues to be optimal, which means that bile acids do not play a role in the absorption process. This observation is in accord with the fact that in cholestyramine treated patients the absorption of prednisolone remains undisturbed (16). In these patients bile acids are almost absent within the entero-hepatic cycle, as these are bound to cholestyramine ( 1 gram of resin bounds about 2 grams of sodium glycocholate (17)). In addition, the results show that steatorrhoea has no influence on prednisolone resorption.
On certain days the excreted amount of prednisolone and its metabolites seems to drop or rise considerably (see for instance patient B (fig. 1 a) on the sixth day, and patient $F$ (fig. $1 \mathrm{~b}$ ) on the twentysecond day); this phenomenon was usually also observed in the concomitantly excreted amount of the bile alcohol 27 -nor-5 $\beta$-cholestane-3 $\alpha, 7 \alpha, 12 \alpha, 24,25$-pentol. However, the excreted amount of the latter substance should be expected to drop or rise smoothly. Therefore these two patients ( $B$ and $F$ ) were selected for a comparison between the urinary excretions of 27-nor$5 \beta$-cholestane- $3 \alpha, 7 \alpha, 12 \alpha, 24,25$-pentol and creatinine (see fig. 2). This figure clearly shows that the excretions of both substances are closely related to one another and, in addition, that the unexpected decreases in the urinary excretion of the bile alcohol also occur in the urinary excretion of creatinine. Therefore in these instances, the 24 hour urine samplings were not correctly performed, resulting in erroneous values. Correction for unreliable urine sampling by giving the excreted amounts of urinary prednisolone per mmol creatinine or per mg 27 -nor- $5 \beta$ cholestane- $3 \alpha, 7 \alpha, 12 \alpha, 24,25$-pentol is only partly justified as shown in figure 2 . This is a consequence of the fact that the urinary excretion of prednisolone and metabolites, unlike that of creatinine and 27-nor$5 \beta$-cholestane-3 $\alpha, 7 \alpha, 12 \alpha, 24,25$-pentol, is not constant during the day, because the times of drug administration are not evenly distributed throughout the day. The rise of the prednisolone $/ 27$-nor-5 $\beta$ cholestane-3 $\alpha, 7 \alpha, 12 \alpha, 24,25$-pentol ratio in urine in 
the latter stages of the post operative treatment is explained by the fact that the 24 hour excretion of the 27-nor-5 $\beta$-cholestane-3 $\alpha, 7 \alpha, 12 \alpha, 24,25$-pentol gradually drops after a successful operation.

In addition to the known prednisolone metabolites, mass spectrometric analysis of peaks 9,10 and 11 (see fig. 4) revealed the existence of other metabolites with nearly identical structures which, to our knowledge, have not hitherto been described. The mass spectrum, shown in figure 4 , suggests the presence of a dihydroxyprednisolone derivative, probably $6 \beta, 20 \beta$-dihydroxyprednisolone.

The mass fragments were assigned as follows:

$$
\begin{aligned}
& \mathrm{m} / \mathrm{z} 677(\mathrm{M}-90)^{+}, 587(\mathrm{M}-2 \times 90)^{+}, \\
& 497(\mathrm{M}-3 \times 90)^{+}, 407(\mathrm{M}-4 \times 90)^{+}, \\
& 317(\mathrm{M}-5 \times 90)^{+} \\
& \mathrm{m} / \mathrm{z} 646(\mathrm{M}-31-90)^{+} \\
& \mathrm{m} / \mathrm{z} 574(\mathrm{M}-103-90)^{+}, \\
& 484(\mathrm{M}-103-2 \times 90)^{+} \\
& \mathrm{m} / \mathrm{z} 562(\mathrm{M}-205)^{+}, 472(\mathrm{M}-205-90)^{+}, \\
& 382(\mathrm{M}-205-2 \times 90)^{+}, \\
& 292(\mathrm{M}-205-3 \times 90)^{+} \\
& \mathrm{m} / \mathrm{z} 515(\mathrm{M}-252)^{+}, 425(\mathrm{M}-252-90)^{+}, \\
& 335(\mathrm{M}-252-2 \times 90)^{+}
\end{aligned}
$$

\section{References}

1. Gambertoglio, J. G., Holford, H. G., Lizak, P. S., Birnbaum, J. L., Salvatierra, O. Jr. \& Amend, W. J. Jr. (1984) Am. J.. Kidney. Dis. 3, 425-429.

2. Pickup, M. E. (1979) Clin. Pharmacokinet. 4, 111-128.

3. Bergrem, H. \& Opedal, I. (1983) Scand. J. Gastroenterol. $18,545-549$.

4. Haynes, R. C. Jr. \& Marud, F. (1980) Adrenocorticotropic hormone; inhibitors of adrenocortical steroid biosynthesis. In: The Pharmacological Basis of Therapeutics (Gilman, A. G., Goodman, L. S., Gilman, A., Mayer, S. E. \& Melamn, K. L., eds.) 6th ed., Macmillan, New York, pp. 1466-1496.

5. Chakraborty, J., Hayes, M., English, J., Baylis, M. \& Markș, V. (1981) Eur. J. Clin. Pharmacol. 19, 79-81.

6. Frey, B. M. \& Frey, F. J. (1982) J. Chromatogr. 229, $283-$ 292.

7. Rocci, M. L. Jr. \& Jusko, W. J. (1981) J. Chromatogr. 224, $221-227$.

8. English, J., Dunne, M. \& Marks, V. (1983) Clin. Pharmacol. Ther. $33 ; 381-385$. $\mathrm{m} / \mathrm{z} 237\left(\mathrm{C}_{1}-\mathrm{C}_{6}+\mathrm{C}_{10}+\mathrm{C}_{19}\right)^{+}$

$147\left(C_{1}-C_{6}+C_{10}+C_{19}-90\right)^{+}$

$\mathrm{m} / \mathrm{z} 205\left(\mathrm{C}_{20}+\mathrm{C}_{21}\right)^{+}, 115\left(\mathrm{C}_{20}+\mathrm{C}_{21}-90\right)^{+}$.

In conclusion prednisolone absorption can conveniently be monitored by measuring the urinary excretion of prednisolone and its metabolites by capillary gas liquid chromatography. The additional measurements of 27 -nor- $5 \beta$-cholestane- $3 \alpha, 7 \alpha, 12 \alpha, 24,25$-pentol provide a means of following the recovery process, and, like the measurement of creatinine, provide a parameter for the correctness of the 24 hour urine collection. Finally our study has provided evidence that prednisolone absorption and metabolism in orthotopic liver transplant patients remains essentially undisturbed, independent of external bile drainage or steatorrhoea.

\section{Acknowledgement}

We are very grateful to Dr. J. G. Bouman for determining faecal fat and to Dr. F. R. Hindriks for determining creatinine in urine. Patient $\mathrm{H}$. was under the care of $M$. C. A. Bijleveld, M.D.

9. Wolthers, B. G., Volmer, M., Van der Molen, J., Koopman, B. J., De Jager, A. E: J. \& Waterreus, R. J. (1983) Clin. Chim. Acta 131, 53-65.

10. Kuwabra, M., Ushiroguchi, T., Kihira, K., Kuramoto, T. \& Hoshita, K. (1984) J. Lipid. Res. 25, $361-368$.

11. Karlaganis, G., Nemeth, A., Hammerskjöld, B., Strandvik, B. \& Sjövall, J. (1981) Eur. J. Clin. Invest. 12, 399-405.

12. Karlaganis, G., Bremmelgaard, A., Karlaganis, V. \& Sjövall, J. (1983) J. Steroid. Biochem. 18, 725-729.

13. Ludwig-Köhn, H., Henning, H. V., Sziedat, A., Matthaei, D., Spiteller, G., Reiner, J. \& Egger, H. J. (1983) Eur. J. Clin. Invest. 13, $91-98$.

14. Van de Kamer, J. H., Ten Bokkel Huinink, H. \& Wijers, H. A. (1949) J. Biol. Chem. 177, 347.

15. Eik-Nes, K. B. \& Horning, E. C. (1968) Gas chromatography of steroids. Springer Verlag, Heidelberg, p. 19 and p. 332.

16. Audetat, V. \& Bircher, J. (1976) Gastroenterology 71, $1110-1111$.

17. Reynolds, J. E. F. (1982) Martindale, The extra pharmacopoeia. The pharmaceutical press, London.

\section{B. J. Koopman}

Central Laboratory

for Clinical Chemistry

P. O. Box 30.001

NL-9700 RB Groningen 
